\title{
BUDAYA KESELAMATAN PASIEN DI RUANG RAWAT INAP
}

\author{
EBIAL FITRI BR GINTING \\ ebyalfitriginting@gmail.com
}

\section{Latar Belakang}

Keselamatan pasien dan mutu pelayanan kesehatan yang tinggi adalah tujuan yang selalu diharapkan oleh rumah sakit, manajer, tim penyedia pelayanan kesehatan, pihak jaminan kesehatan, serta pasien, keluarga dan masyarakat. Namun demikian, prinsip "First, do no harm" tidak cukup kuat untuk mencegah berkembangnya masalah keselamatan pasien. Utarini, et al, (2012). Rumah sakit melakukan upaya untuk meningkatkan keselamatan pasien sebagai berikut, melalui program enam sasaran keselamatan pasien. Budaya keselamatan adalah nilai,keyakinan, perilaku yang dianut individu dalam suatu organisasi mengenai yang memprioritaskan dan mendukung peningkatan keselamatan. Budaya keselamatan pasien merupakan nilai, sikap, persepsi, kompetensi dan pola perilaku individual dan kelompok yang menentukan komitmen dan cara organisasi dalam keselamatan pasien (Nivalinda, et al,2013).

Budaya keselamatan pasien dapat diukur melalui standar pengukuran budaya keselamatan pasien yang dikembangkan beberapa organisasi. Beberapa oragnisasi yang mengembangkan standar pengukuran tersebut yaitu, Agency of Healthcare Research and Quality (AHRQ), Manchester Patient Survey Assesment Framework (MaPSaF) yang menyatakan bahwa terdapat beberapa komponen dalam survey budaya keselamatan pasien. Meskipun adanya perbedaan jumlah elemen, namun instrumen digunakan untuk mengukur komponen yang ada pada budaya keselamatan pasien yaitu budaya keterbukaan (Informed Culture), keadilan (Just Culture), pembelajaran (Learning Culture), pelaporan (Reported Culture) (AHRQ, 2015).

Membangun budaya keselamatan pasien memungkinkan seluruh staf rumah sakit dapat meningkatkan keselamatan pasien didukung oleh peran kepala ruangan yang optimal. Upaya kepala ruangan dalam melaksanakan peran yang efektif diruangannya dapat mempengaruhi budaya keselamatan pasien. Penelitian ini bertujuan 
untuk mengetahui peningkatan budaya keselamatan pasien melalui peningkatan motivasi perawat dan optimalisasi peran kepala ruang.

Keselamatan pasien di rumah sakit (Hospital Patient Safety)merupakan suatu sistem pelayananrumah sakit yang memberikan asuhan agar pasien menjadi lebih aman. Termasuk didalamnya adalah mengukur risiko, identifikasi,dan pengelola risiko terhadap pasien, pelaporan, dan analisis insiden, kemampuan untuk belajar dan menindaklanjuti insiden serta merupakan solusi untuk mencegah, mengurangi, serta meminimalkan risiko.

\section{Metode}

Metode yang digunaka adalah metode kualitatif dimana maksudnya dengan cara mengumpulkan sebanyak-banyaknya data untuk dianalisis. Yaitu dengan Literature review ini dengan menganalisis yang berfokus pada budaya keselamatan pasien di rumah sakit dalam meningkatkan mutu pelayanan di rumah sakit. Adapun tinjauan literatur yang digunakan seperti buku teks, bukureferensi, jurnal, dan google scholar.Dengan kata kunci budaya Keselamatan pasien, keselamatan pasien di rumah sakit, meningkatkan mutu pelayanan.Dan yang digunakan adalah 14 literatur yang diterbitkan 10 tahun terakhir.

Hasil

Rumah sakit merupakan suatu wadah pelayanan kesehatan yang utama. Dengan demikian rumah sakit harus mampu memberikan pelayanan kesehatan yang terintegrasi pada pasien sebagai penguna layanan. Membangun gerakan keselamatan pasien di rumah sakit merupakan prioritas utama pada layanan rumah sakit. akan menguntungkan berbagai pihak baik itu rumah sakit maupun pasien sebagai pengguna layanan kesehatan (KKPRS, 2015).

Budaya keselamatan pasien merupakan kewajiban dan tanggung jawab seluruh pegawai. Pengawai adalah bagian dari organisasi merupakan ujung tombak dalam budaya keselamatan pasien (Amarapathy, Sridharan, Perera, \& Handa, 2013). Di 
samping itu organisasi rumah sakit sebagai pemberi pelayanan kesehatan harus mampu menerima keselamatan sebagai nilai baru dalam budaya organisasi dengan komitmen berani berubah, berubah dalam arti blaming cultur menjadi safety cultur (Cahyono, 2008).

Budaya keselamatan pasien merupakan langkah utama dalam meningkatkan keselamatan pasien. Pemimpin merupakan motor penggerak untuk melakukan aktifitas sesuai dengan yang diharapkan organisasi. Promosi budaya keselamatan pasien yang baik merupakan pelaksanaan dari intervensi yang mendasar dari kepemimpinan yang akan merubah perilaku anggota tim(Weaver et al., 2013).

Pembahasan

Keselamatan pasien (patient safety) dapat diartikan sebagai upaya untuk mencegah suatu bahaya yang akan terjadi pada pasien. Konsep keselamatan pasien harus mampu dilaksanakan secara menyeluruh dan terpadu. Menurut The American Hospital Asosiation (AHA) 1999 keselamatan dan keamanan pasien ( patient safety), keutamaan strategik. Patient safety, sebuah sistem yang mampu memberikan rasa aman kepada pasien. Sistem pada Patient safety yang disebabkan oleh kesalahan dalam pengambilan tindakan dapat memperingankan cedera yang akan terjadi. Keselamatan pasien menurut Sunaryo (2009) adalah ada tidak adanya kesalahan atau bebas dari cidera karena kecelakaan.Patient safety mulai dicanangkan di Australia pada tahun 2000 oleh Ministry of Health (MOH) Australia.Di Indonesia sendiri dibentuk Komite Keselamatan Pasien Rumah Sakit (KKPR) pada tahun 2005 oleh Persatuan Rumah Sakit Indonesia (PERSI).Di Indonesia PERSI yang pertama kali membentuk dan menginisiasi Gerakan keselamatan pasien rumah sakit, yang diresmikan / dicanangkan oleh Menteri Kesehatan pada Pembukaan Seminar Nasional PERSI tanggal 21 Agusus 2005.Dugaan malpraktek yang dilakukan petugas pelayanan kesehatan yang mengakibatkan pasien mengalami kerugian mulai dari materi, cacat fisik bahkan sampai meninggal dunia memperlihatkan masih rendahnya mutu pelayanan kesehatan di rumah sakit.patient safety (keselamatan pasien) belum menjadi budaya yang harus diperhatikan oleh rumah sakit di Indonesia. Perubahan paradigma dalam lembaga pelayanan kesehatan yang saat ini beralih pada patient centered care belum benar- 
benar dijalankan dengan baik. Masih ada rumah sakit yang berorientasi pada kepentingann manajemen yang pada akhirnya melupakan keselamatan pasien di rumah sakit. Undangundang Kesehatan no 36 tahun 2009 sudah dengan jelas bahwa rumah sakit saat ini harus mengutamakan keselamatan pasien diatas kepentingan yang lain sehingga sudah seharusnya rumah sakit berkewajiban menerapkan budaya keselamatan pasien.

Tidak ada lagi alasan bagi setiap rumah sakit untuk tidak menerapkan budaya keselamatan pasien karena bukan hanya kerugian secara materi yang didapat tetapi juga ancaman terhadap hilangnya nyawa pasien.Apabila masih ada rumah sakit yang mengabaikan keselamatan pasien sudah seharusnya diberi sanksi yang berat baik untuk rumah sakit maupun petugas pelayanan kesehatan.Beberapa kasus yang terjadi di Indonesia, pihak rumah sakit bahkan petugas pelayanan kesehatan tidak mendapat sanksi apapun sehingga menjadikan penegakan hukum kesehatan di Indonesia masih sangat lemah. Sudah seharusnya apabila terjadi kelalaian bahkan kesengajaan dari pihak rumah sakit yang mengakibatkan terancamnya keselamatan pasien maka tidak hanya sanksi internal tetapi juga sudah masuk ke ranah pidana. Inilah yang sampai saat ini belum berjalan sehingga masyarakat yang dirugikan karena lemahnya penegakan hukum yang pada akhirnya kasusnya menguap begitu saja.

Ada beberapa faktor yang menajdi penyebab kenapa budaya keselamatan pasien belum benar-benar diterapkan di berbagai rumah sakit.Pertama, rendahnya tingkat kepedulian petugas kesehatan terhadap pasien, hal ini bisa dilihat dengan masih ditemukannya kejadian diskriminasi yang dialami oleh pasien terutama dari masyarakat yang tidak mampu.Kedua, beban kerja petugas kesehatan yang masih terlampaui berat terutama perawat. Perawatlah yang bertanggung jawab terkait asuhan keperawatan kepada pasien sedangkan disisi lain masih ada rumah sakit yang memiliki keterbatasan jumlah perawat yang menjadikan beban kerja mereka meningkat. Selain perawat, saat ini di Indonesia juga masih kekurangan dokter terutama dokter spesialis serta distribusi yang tidak merata. Ini berdampak pada mutu pelayanan yang tidak sama di setiap rumah sakit. ketiga, orientasi pragmatisme para petugas kesehatan yang saat ini masih melekat disebagian petugas kesehatan. Masih ditemukan para petugas kesehatan yang 
hanya berorientasi untuk mencari materi/keuntungan semata tanpa mempedulikan keselamatan pasien. Keempat, lemahnya pengawasan yang dilakukan oleh dinas kesehatan terhadap para petugas kesehatan. Lemahnya pengawasan sendiri dikarenakan beberapa faktor mulai dari terbatasnya personel yang dimiliki dinas kesehatan sampai rendahnya bargaining position dinas kesehatan. Keempat hal tersebut diatas yang setidaknya menjadi penghalang terwujudnya budaya keselamatan pasien di setiap rumah sakit.jika hal ini tidak segera diselesaikan maka kasus-kasus yang mengancam keselamatan pasien akan terus terjadi sehingga perlu upaya yang maksimal untuk mewujudkan budaya keselamatan pasien. Mulai diterapkannya aturan baru terkait akreditasi rumah sakit versi 2012 menjadi sebuah harapan baru agar budaya keselamatan pasien bisa diterapkan diseluruh rumah sakit di Indonesia.Selain itu, harus ada upaya untuk meningkatkan kesadaran para pemberi pelayanan kesehatan tentang pentingnya menerapkan budaya keselamatan pasien dalam setiap tindakan pelayanan kesehatan. Dan juga diperlukan sosialisasi yang masif kepada masyarakat terutama yang akan menggunakan jasa pelayanan kesehatan untuk meningkatkan pengetahuan serta memperbaiki perilaku mereka dalam memanfaatkan pelayanan kesehatan.

Upaya-upaya ini harus segera dilakukan agar tidak ada lagi kasu dugaan malpraktik yang dapat merugikan masyarakat sehingga mutu pelayanan kesehatan di rumah sakit bisa meningkat.Dengan meningkatkan kepedulian terhadap pasien maka dengan mudah budaya keselamatan pasien bisa dijalankan.Jangan sampai hanya karena kesalahan sedikit yang dilakukan oleh rumah sakit bisa berakibat pada rusaknya citra dunia perumah sakitan di Indonesia dimata internasional.

\section{Penutup}

Dalam penerapan program keselamatan pasien terdapat beberapa aspek yang mempengaruhi berjalannya program penerapan keselamatan pasien. Aspek-aspek tersebut antara lain: iklim organisasi, tingkat pengetahuan, komunikasi, dan etika. Budaya keselamatan pasien akan tercipta apabila tenaga kesehatan memiliki pemimpin yang bersedia bekerja sama demi terlaksananya patient safety. Selain itu pengetahuan dan komunikasi juga berpengaruh terhadap ter:aksananya patient safety. Salah satu 
aspek yang penting dalam terlaksananya patient safety yaitu aspek etika. Etika sangatlah penting karena akan menyangkut tentang prosedur dalam melaksanakan asuhan keperawatan atau melaksanakan tugas dalam melayani kesehatan. Dalam pelayanan kesehatan maka tenaga medis harus sesuai dengan kode etik dan hukum kesehatan.Hal ini untuk menghindari atau mengurangi praduga terjadinya malpraktik.

\section{Daftar pustaka}

Herawati, Y., T. (2015). Budaya Keselamatan Pasien di Ruang Rawat Inap Rumah Sakit X Kabupaten Jember. Jurnal Ikatan Kesehatan Masyarakat. 11(1), 54-58.

Najihah. (2018). Budaya Keselamatan Pasien dan Insiden Keselamatan Pasien Di Rumah Sakit: Literature Review. Journal Of Islamic Nursing. 3 (1), 1-4.

Cahyono, A. (2015). Hubungan karakteristik dan tingkat pengetahuan Perawat terhadap pengelolaan keselamatan Pasien di rumah sakit. Jurnal IImiah WIDYA, 1(1), 97-99.

Mei,R ,W, Dkk. (2019). Peningkatan Budaya Keselamatan Pasien Melalui Peningkatan Motivasi Perawat dan Optimalisasi Peran Kepala Ruang. Jurnal Kepemimpinan dan Manajemen Keperawatan, Vol 2 No 2, November 2019.

Yeni,Y, Maswarni. (2019). Budaya keselamatan pasien pada perawat di instalasi perawatan intensif RSUD ARIFIN ACHMAD Provinsi Riau. Jurnal Keperawatan Priority, Vol 2, No. 2, Juli 2019.

Agustina, P, Dkk.(2014). Budaya keselamatan pasien di instalasi rawat inap RSUP DR. WAHIDIN SUDIROHUSODO Kota Makassar. Jurnal MKMI, hal 57-64, Maret 2014.

Najihah. (2018). Budaya Keselamatan Pasien dan Insiden Keselamatan Pasien Di Rumah Sakit: Literature Review. Journal Of Islamic Nursing. 3 (1), 1-4.

Yasmi, Y., \& Thabrany, H. (2018). Faktor-Faktor yang Berhubungan dengan Budaya Keselamatan Pasien di Rumah Sakit Karya Bhakti Pratiwi Bogor Tahun 2015. Jurnal Administrasi Rumah Sakit. 4 (2), 99-103. 
Pujilestari, A. (2013). Gambaran Budaya Keselamatan Pasien Oleh Perawat Dalam Melaksanakan Pelayanan Di Instalasi Rawat Inap RSUP Dr. Wahidin Sudirohusodo Tahun 2013. Jurnal Kesehatan Masyarakat, 1-13.

Ultaria, T. D. (2017). Gambaran Budaya Keselamatan Pasien Di RS Roemani Muhamaddiyah Semarang. Jurnal Kesehatan Masyarakat, 5(1), 118-125.

Simamora, R ,H,\& Fathi, A. (2019). The Influence Of Training Handover Based SBAR Communication For Improving Patients Safety. Indian Journal of public health research \& development, 10(9), 1280-1285. 